\title{
The in vitro metabolism of 25 -hydroxycholecalciferol by pig kidney: effect of low dietary levels of calcium and phosphorus
}

\author{
By BARBARA A. SOMMER VILLE, J. FOX AND A. D. CARE \\ Department of Animal Physiology and Nutrition, University of Leeds, Leeds LS2 $9 J T$ \\ AND R. SWAMINATHAN \\ Department of Chemical Pathology, The General Infirmary, Leeds LS I $3 E X$
}

(Received I6 January 1978-Accepted 22 March 1978)

\begin{abstract}
I. Homogenates of pig kidney incubated in vitro convert 25-hydroxycholecalciferol to the dihydroxymetabolites almost as efficiently as homogenates of chick kidney under similar conditions.

2. The cortex of the kidney carries out this conversion more efficiently than does the medulla.

3. Kidneys from pigs given low calcium or low phosphorus diets produce about $40 \%$ more 1,25 -dihydroxycholecalciferol than those from pigs given diets containing normal levels of $\mathrm{Ca}$ and $\mathbf{P}$.
\end{abstract}

Cholecalciferol (vitamin $D_{3}$ ) is hydroxylated in the liver to form 25-hydroxycholecalciferol (25-HCC) (Ponchon, Kennan \& DeLuca, 1969). This is the major circulating metabolite and is hydroxylated again in the renal tubule cells to the most active metabolite of vitamin $\mathrm{D}_{3}$, I,25-dihydroxycholecalciferol (I,25-DHCC; Frazer \& Kodicek, 1970) or to a less-active metabolite, 24,25 -dihydroxycholecalciferol $(24,25$-DHCC) the role of which is unclear (Holick, Schnoes, DeLuca, Gray, Boyle \& Suda, 1972). In birds, the activity of the renal 25-HCC-I-hydroxylase (I-hydroxylase) is stimulated by low-calcium diets (Henry, Midgett \& Norman, 1974; Omdah1, Gray, Boyle, Knutson \& DeLuca, 1972; Swaminathan, Sommerville \& Care, 1977) and by very low phosphorus diets (Baxter \& DeLuca, 1976; Swaminathan, Sommerville \& Care, 1978). Under the effects of such stimulation, a larger amount of $\mathrm{I}, 25-\mathrm{DHCC}$ is accumulated in the intestinal mucosa resulting in an increase in the rate of absorption of $\mathrm{Ca}$ and an increase in the synthesis of $\mathrm{Ca}$-binding protein (CaBP) (Corradino, 1973).

Although the presence of a renal I-hydroxylase has been demonstrated in eight species of mammals (Henry \& Norman, 1975), the in vitro conversion rates tend to be low compared with the chick and the factors regulating the metabolism of $25-\mathrm{HCC}$ in the mammal have been studied only in the rat by employing in vivo techniques'(Garabedian, Holick, DeLuca \& Boyle, 1972; Tanaka, Frank \& DeLuca, 1973; Rosenthal, Jones, Kooh \& Frazer, 1977). On finding that kidney homogenates from young pigs converted $25-\mathrm{HCC}$ almost as efficiently as those from chicks, it was decided to see whether the in vitro metabolism of $25-\mathrm{HCC}$ in this species followed a similar pattern to that of the bird.

\section{MATERIALS AND METHODS}

Six, young Large-White pigs (on various treatments) were tranquillized by an intramuscular injection of etorphine and acepromazine (Large Animal Immobilon, Reckitt \& Colman Co. Ltd, Hull) and exsanguinated. Immediately after death a kidney was removed, cooled on ice and thin slices were taken from just beneath the capsule (peripheral cortex), from near the cortico-medullary junction (deep cortex) and from the medulla.

Two, 3-month-old littermate pigs were given a diet containing $(/ \mathrm{kg}) 300$ IU vitamin $\mathrm{D}_{3}$ and either $8 \mathrm{~g} \mathrm{Ca}$ and $7 \mathrm{~g} \mathrm{P}$ or, $\mathrm{r} \mathrm{g} \mathrm{Ca}$ and $7 \mathrm{~g} \mathrm{P}$ for $\mathrm{I} 4 \mathrm{~d}$. A similar pair of littermates were 
Table I. Comparison of the efficiency of conversion of 25-hydroxycholecalciferol (25-HCC) by different regions of the pig kidney

$\begin{array}{rlc} & \text { Deep cortex } & \text { Medulla } \\ \text { 24,25-DHCC (6) } & 69 \cdot 3 \pm 5 \cdot 9^{* *} & 44 \cdot 1 \pm 4 \cdot 6^{* * *} \\ \text { I,25-DHCC (6) } & 87 \cdot 2 \pm 7 \cdot 0 \mathrm{NS} & 46 \cdot 5 \pm 8 \cdot \mathrm{I}^{* * *}\end{array}$

Separate incubations were carried out with $10 \%$ homogenates from three regions of the kidneys of six pigs and the conversion of $25-\mathrm{HCC}$ to 1,25 -dihydroxycholecalciferol $(1,25$-DHCC) or 24,25 -dihydroxycholecalciferol $(24,25-D H C C)$ in the deep cortex or medulla expressed as a mean percentage $( \pm \mathrm{SE})$ of that found in the peripheral cortex. Statistical analysis by paired $t$ test.

NS, not significant; ${ }^{* *} P<0.01 ;{ }^{* *} P<0.001$. Numbers of observations in parentheses.

given a diet containing vitamin $\mathrm{D}_{3}$ and either $(\mathrm{g} / \mathrm{kg})$ I $2 \mathrm{Ca}$ and $7 \mathrm{P}$ or, $12 \mathrm{Ca}$ and $3 \mathrm{P}$ for $14 \mathrm{~d}$. The pigs were killed as described above and slices of peripheral cortex were taken from a kidney of each animal.

One part by weight of each slice was homogenized in ten parts of $15 \mathrm{~mm}$-Tris-acetate buffer $(\mathrm{pH} 7.4$ ) containing 1.9 mM-magnesium chloride, $5 \mathrm{~mm}$-sodium succinate and $200 \mathrm{~mm}$-sucrose by grinding in a Potter-Elvehjem homogenizer. Three $5 \mathrm{ml}$ portions of each homogenate were placed in $25 \mathrm{ml}$ Erlenmeyer flasks, flushed with oxygen for $30 \mathrm{~s}$ and pre-incubated for $5 \mathrm{~min}$ at $37^{\circ}$. At the end of the pre-incubation period, $160 \mathrm{pmol} 25-[26,27-$ $\left.{ }^{3} \mathrm{H}\right] \mathrm{HCC}$ ( $\mathrm{I} \cdot \mathrm{I} \mathrm{Ci} / \mathrm{mmol}$; Radiochemical Centre, Amersham, Bucks.), dissolved in $20 \mu \mathrm{l}$ aqueous ethanol $(980 \mathrm{ml} / \mathrm{l})$, was added to each incubation mixture and the flask flushed with oxygen for a further $30 \mathrm{~s}$. The flasks were incubated at $37^{\circ}$ for $\mathrm{I} h$ and then rapidly cooled to $-20^{\circ}$ and stored until extraction. Lipid extracts of the incubation mixture were prepared and chromatographed on Sephadex LH20 (Pharmacia Ltd, Uppsala, Sweden) in a $0.55 \times 0.014 \mathrm{~m}$ glass column (flow rate $0.7 \mathrm{ml} / \mathrm{min}$ ) with chloroform-hexane $(65: 35 \mathrm{v} / \mathrm{v}$ ) eluent and counted as described by Swaminathan et al. (1977).

The concentrations of $\mathrm{Ca}$ and inorganic phosphate in the plasma were determined by automated methods (Technicon Instruments Co. Ltd, 1966).

\section{RESULTS}

Table I shows that the medulla converted less than half the amount of $25-\mathrm{HCC}$ to the dihydroxy metabolites that was converted by the peripheral cortex. The deep cortex did not show much reduction in the amount of $\mathrm{I}, 25$-DHCC produced although markedly less $(70 \%) 24,25$-DHCC was produced compared with the peripheral cortex.

Table 2 shows that the amount of 1,25-DHCC produced was about $25 \%$ of the total count in the pigs given the normal $\mathrm{Ca}$ and $\mathrm{P}$ diets and this increased to about $40 \%$ of the total count in the pigs given the low-Ca or low-P diets.

It is possible that some of the activity accorded to I,25-DHCC might be due to 25,26 DHCC since these two metabolites are indistinguishable using $\mathrm{LH}_{20}$ columns.

\section{DISCUSSION}

The results demonstrate that, under the specified incubation conditions, the kidneys of 3-month-old pigs given a diet containing adequate amounts of $\mathrm{Ca}, \mathrm{P}$ and vitamin $\mathrm{D}$ ('normal' diet), will convert about $30 \%$ of the labelled 25 -HCC to the dihydroxy metabolites. This is about the same degree of conversion achieved by 3-week-old chick kidneys under identical conditions (Sommerville, unpublished results). Henry \& Norman (1975) and Midgett, 
Table 2. Effects of low dietary levels of calcium or phosphorus on the in vitro metabolism of $25-\left[26,27^{-3} \mathrm{H}\right]$ hydroxycholecalciferol $(25-H C C)$ by the peripheral cortex of the pig kidney

(Means and standard errors of three incubations from each kidney. One pig per dietary group)

\begin{tabular}{|c|c|c|c|c|}
\hline \multirow[b]{2}{*}{ Diet } & \multicolumn{2}{|c|}{$\begin{array}{l}\text { Plasma concentration } \\
(\mathrm{mmol} / \mathrm{l})\end{array}$} & \multicolumn{2}{|c|}{$\begin{array}{c}\text { Renal enzyme activity } \\
\text { (pmol/g kidney per incubation) }\end{array}$} \\
\hline & $\mathrm{Ca}$ & $\mathbf{P}$ & I-hydroxylase* & 24-hydroxylase* \\
\hline $\begin{array}{l}\text { Normal Ca } \\
\text { Low Ca } \\
\text { Normal P } \\
\text { Low P }\end{array}$ & $\begin{array}{l}2 \cdot 60 \\
2.45 \\
2 \cdot 60 \\
3 \cdot 20\end{array}$ & $\begin{array}{l}- \\
2 \cdot 68 \\
1 \cdot 77\end{array}$ & $\begin{array}{r}85.4 \pm 9 \cdot 0 \\
128 \cdot 0 \pm 6.4 \\
78 \cdot 1 \pm 5 \cdot 4 \\
125 \cdot 1 \pm 10.9\end{array}$ & $\begin{array}{c}16.3 \pm 0.3 \\
26.6 \pm 2.6 \\
46.4 \pm 5.1 \\
16.6 \pm 0.6\end{array}$ \\
\hline
\end{tabular}

Spielvogel, Coburn \& Norman (1976) reported that there is considerable species variation in the capacity of the mammalian kidney to hydroxylate $25-\mathrm{HCC}$ in vitro although the pig was not among the species that they tested. Botham, Tanaka \& DeLuca (1974) incubated kidney homogenates from adult pigs on a very high daily intake of vitamin $\mathrm{D}_{2}$ and found, predictably, that only $24,25-\mathrm{DHCC}$ was produced. They confirmed previous findings (Henry \& Norman, I975; Midgett et al. 1976) that rat kidney homogenates converted very little $25-\mathrm{HCC}$ in vitro and they also found that kidney homogenates or serum from rat or pig would inhibit the capacity of the chick kidney homogenates to convert 25 - $\mathrm{HCC}$ to I,25-DHCC. This inhibitory effect is due to a $25-\mathrm{HCC}$-binding protein present in mammalian kidney tissue which has a greater affinity for the substrate 25 -HCC than does the chick I-hydroxylase (Botham, Ghazarian, Kream \& DeLuca, 1976). The results presented here suggest that the pig renal I-hydroxylase is able to compete successfully with this binding protein.

Midgett et al. (1976) found that $25-\mathrm{HCC}$ conversion took place only in the cortex of the dog kidney and none occurred when homogenates were made from the medullary region. The present results show that $25-\mathrm{HCC}$ is converted by the medulla of the pig kidney to both I,25-DHCC and 24,25-DHCC but at a much lower rate than by the cortex. Whereas little difference in the activity of the I-hydroxylase was found between the peripheral and deep cortex, the activity of the 24 -hydroxylase was lower in the deep cortex. One explanation of these findings is that the enzymes exist independently of each other and may have a slightly different anatomical distribution. The inhibitory effect of endogenous I,25-DHCC on renal I-hydroxylase activity along with a stimulating action on the corresponding 24-hydroxylase implies that the two enzymes are quite distinct (Spanos, Barrett \& MacIntyre, 1978). The peripheral cortex would contain a somewhat higher ratio of convoluted renal tubules to straight tubules and collecting ducts than does the cortex at the cortico-medullary junction and so there may be a greater concentration of 24 -hydroxylase in the convoluted renal tubules.

The results of the present experiments show that an increase in I-hydroxylase activity occurs in response to a low-Ca and a low-P diet in the pig. In the chick, such an increase is greater in response to a low-Ca diet than it is to a low-P diet (Sommerville, Swaminathan \& Care, 1978) and would be negligible on a diet containing as much as $3 \mathrm{~g} \mathrm{P} / \mathrm{kg}$. (Swaminathan et al. 1978). This limitation was not evident in the pig. Haussler, Hughes, Baylink, Littledike, Cork \& Pitt (1977), using a radio-receptor assay, reported that in pigs given a low$P$ diet, circulating levels of $1,25-\mathrm{DHCC}$ increased 3 - to 4 -fold. This finding is compatible with our's that kidneys from pigs given a diet low in $\mathrm{Ca}$ or $\mathrm{P}$ show a greater activity of the 25-HCC-I-hydroxylase than those on a normal diet. 
Financial assistance from the Medical Research Council to A.D.C. is gratefully acknowledged and also the technical assistance of J. R. Dowson.

\section{REFERENCES}

Baxter, L. A. \& DeLuca, H. F. (1976). J. biol. Chem. 25I, 3158.

Botham, K. M., Tanaka, Y. \& DeLuca, H. F. (1974). Biochemistry 13, 496I.

Botham, K. M., Ghazarian, J. G., Kream, B. E. \& DeLuca, H. F. (I976). Biochem. J. 15, 2130.

Corradino, R. A. (1973). J. cell Biol. 58, 64.

Frazer, D. R. \& Kodicek, E. (1970). Nature, Lond. 228, 764.

Garabedian, M., Holick, M. F., DeLuca, H. F. \& Boyle, I. T. (1972). Proc. natn. Acad. Sci. U.S.A. 69, 1673.

Haussler, M. R., Hughes, M. R., Baylink, D. T., Littledike, E. T., Cork, D. \& Pitt, M. (I977). Adv, Med. Biol. 8r, 233.

Henry, H. L., Midgett, R. J. \& Norman, A. W. (1974). J. biol. Chem. 249, 7584.

Henry, H. L. \& Norman, A. W. (1975). Comp. Biochem. Physiol. 50 B, 431.

Holick, M. F., Schnoes, H. K., DeLuca, H. F., Gray, R. W., Boyle, I. T. \& Suda, T. (1972). Biochemistry Ir, $425 I$.

Midgett, R. J., Spielvogel, A. M., Coburn, J. W. \& Norman, A. W. (I973). J. clin. Endocr. Metab. 36, I 53

Omdahl, J. L., Gray, R. W., Boyle, I. T., Knutson, J. \& DeLuca, H. F. (1972). Nature, New Biol. 237, 63.

Ponchon, G., Kennan, A. L. \& DeLuca, H. F. (I969). J. clin. Invest. 48, 2032.

Rosenthal, A. M., Jones, G., Kooh, S. W. \& Frazer, D. (1977). Proceedings and Abstracts 6 th Parathyroid. Conference, University of British Columbia, Canada, June 12-17, 1977, p. 159.

Sommerville, B. A., Swaminathan, R. \& Care, A. D. (1978). Br. J. Nutr. 39, 4 I r.

Spanos, E., Barrett, D. I. \& MacIntyre, I. (1978). J. Endocr. (In the Press.)

Swaminathan, R., Sommerville, B. A. \& Care, A. D. (I977). Br. J. Nutr. 38, 47.

Swaminathan, R., Sommerville, B. A. \& Care, A. D. (1978). Clin. Sci. Mol. Med. 54. (In the Press.)

Tanaka, Y., Frank, H. \& DeLuca, H. F. (1973). Science, N.Y. 181, 564.

Technicon Instruments Co. Ltd (I966). Technicon Methodology Sheets N-3b, 4 b. Basingstoke, Hants: Technicon Instruments Co. Ltd. 